\title{
A Demands Of Combated Demands Criminal Crime Of Corruption Criminal Accounts Money Laundering
}

\author{
July Esther \\ Criminal Law HKBP Nommensen of University Medan, Indonesia \\ julyuhn@gmail.com
}

\begin{abstract}
Corruption is one of the original criminal acts (Predicate Crime) in the crime of money laundering. The development of the mode of occurrence of criminal acts of corruption accompanied by money laundering requires legal thinking in the enforcement and handling of these criminal acts. As a mode to fool law enforcement officials, perpetrators of criminal acts of corruption have disguised and concealed the proceeds of crime by laundering money. As a result law enforcement that has been enforced so far only revolves around prosecutors' demands that only demand criminal acts of corruption or money laundering. Looking at the losses that have been incurred due to criminal acts of corruption and money laundering, it is necessary to have a method of merging criminal charges for corruption which is accompanied by money laundering. This research is a normative legal research using a problem approach in the form of case studies of Court Decisions and a legislative approach, namely the Corruption Crime Act and the Money Laundering Act. Sources of legal material that are processed qualitatively are primary data in the form of court decisions, secondary data in the form of laws, and tertiary data that support primary and secondary data. This research results in a legal thinking that corruption as a predicate crime from money laundering can be combined with the prosecution by the Public Prosecutor. The merging of these prosecutions has efficient benefits such as tracking assets that have been washed and maximizing the return of assets through the seizure of assets that can be proven both in investigations, prosecutions and through judicial review. From these results the authors expect that improvements in terms of rules and activities can be coordinated eradication between law enforcement agencies both the Police, the Prosecutor's Office, Corruption Eradication Commission (KPK), and the Center for Financial Transaction Reports and Analysis (PPATK) in combining prosecutions of corruption and corruption money laundering. So that the verdict to be handed down by the judge can restore the state's financial losses and fulfill a sense of justice in the community and achieve the goal of punishment.
\end{abstract}

Keywords: Combated Demands, Corruption, and Money Laundering. 


\section{Introduction}

Efforts to eradicate corruption in Indonesia have been carried out for more than 60 years, both in the era of the old order, the new order, as well as reforms, as well as the new era of government at this time. All the power and efforts that have been made by the government and all levels of society in tackling corruption have not shown the expected results.Corruption crimes are essentially associated with power; state, state finances as well as can result in adverse influences on a country. Corruption weighs the poor. Corruption also creates a high-economic risk of macro, endangers financial stability, compromising security and public order and law, and above all, corruption degrades the legitimacy and credibility of the country in the eyes of the people (Kristiana, 2015).The risks are influenced by the characteristics of corruption crimes that are not only common in general criminal acts. Essentially characteristics of criminal acts of corruption are categorized as white collar crime, organized crime (organized crime), the Crime of transnational organized crime, criminal acts corruption as a criminal act of extraordinary impact (Extra Ordinary Crime), and as a crime with new dimension of crime (Kristian, 2015).Such characteristics, the perpetrators basically do not look at the profession or institution which is the place of practice of corruption, and will face risks if the prevention and enforcement of corruption is not optimized.

In addition to the characteristics of the corruption criminal act above, the rapid development of today's technology has influenced the corruption crime mode which is a challenge in the eradication of corruption crimes. The current technological developments have been utilized by the perpetrators of corruption crimes to conceal the outcome of the criminal act, both through banking institutions, capital markets, overseas investment, as well as other acts aimed at Conceal or disguise the origin of money or property obtained from corruption criminal results. Such actions are often with money laundering terms (Money Laundering). The crime occurs when there is a wealth/fortune gained from the results of a criminal act of corruption to be enjoyed, concealed or received from another person whom he essentially knows is a result of a criminal act.Popularly, money laundering can be explained that money laundering is an act of transferring, using or carrying out other acts resulting from a criminal act that is often committed by criminal organizations, as well as individuals who commit acts of corruption, bribery, narcotics trafficking, forestry crimes, environmental crimes life and other criminal acts with the intention of hiding, disguising or obscuring the origin of money originating from the proceeds of crime (Halim, 2018). This is what is called a predicate crime.The result of money laundering against a country is very large, either loss of state-owned funds or distrust of investment in the economic world. Money 
laundering and financial crime can result in changes that cannot be explained caused by the number of requests for money (money demand) and increase the volatility of the current International Capital Flows, interest rates and currency exchange rate. The unpredictable nature of money laundering led to the loss of government control over its economic policies. Money laundering is another side of the corruption that cannot be ruled out because of corruption it is one of the benefits or the resulting advantage that the asset or property is utilized. When the asset or property has been acquired, it can be ensured, either sooner or later, either directly or indirectly, and then the asset of the property will be utilized. This is where there is closeness between corruption and money laundering (Kristiana, 2015).

Even The Word Bank has made a study in collaboration with FIUs Malawi (a lowincome country) and Namimbia (an upper-middle-income country) that investigates the relationship between corruption and money laundering. From the study, corruption became one of the main sources of the predicate crime in money laundering. Money laundering crimes are also a crime with special characteristics (similar to the corruption crime characteristics above) and are a point of decline and how to eradicate the economic crimes against crimes not only by eradicating Crimes of his Origin but also pursued the outcome of the crime (Gernasih, 2017).This is the basis of the need for the prevention of preventive collaboration as well as the enforcement of corruption crimes and money laundering crimes. The effort is in line with The United Nation Convention against Corruption 2003 (The Anti-corruption Treaty of The year 2003) which has been ratified by Indonesia by Law No. 7 of 2006.The convention regulates explicitly and clearly regarding the efforts that can be carried out by a state party in the framework of prevention (eradication and eradication) of criminal acts of corruption starting from chasing and arresting perpetrators of corruption, tracing assets obtained from criminal acts of corruption, holding agencies accountable law (corporation), inter-state cooperation agreements in handling corruption, return of assets resulting from criminal acts of corruption and so on (Halim, 2018).

Furthermore in general in Article 23: Laundering of proceeds of crime The United Nations Convention Against Corruption (UNCAC) states that participating countries are obliged to determine crimes, actions intended to hide the wealth of proceeds of crime (Kristian, 2015 ). This reiterates that corruption is inseparable from money laundering. This synchronization is needed to achieve law enforcement efficiency in Indonesia.Problems occur at the enforcement stage, there are indictments or judges' considerations that are not in accordance with what is desired by the theory and the mandate of the law. This will become serious because in the indictment on corruption which also contains a money laundering crime or vice versa when it is known that there is a money laundering crime originating from a criminal act of corruption, then 
the indictment is compiled not in one file. In addition there is a tendency to be in a hurry in proving that the crime is corrupt and directly linked to the crime of money laundering. The criminal act of corruption must be proven first in the trial, then the crime of money laundering is proven later in the trial which is not separate. A strategic approach using the Law on Money Laundering in disclosing crimes (in this case corruption) is intended to prevent the perpetrators of crimes from enjoying the crime (Lawrence, 1992).Furthermore, by preventing the perpetrators from enjoying the crime is expected motivation or intention to conduct corruption also disappears, or at least reduced (Scott, 1996). Specifically, it sought to answer the following questions:

(1) What is the legal basis for the merger of corruption and money laundering prosecution?

(2) Why is it necessary to merge corruption criminal prosecution and money laundering?

\section{Research Design And Methodology}

This research uses normative legal research methods with a case study approach. Normative legal research method, which is the method of legal research by conducting analysis on the principles of the law with reference to the legal norms contained in the legislation that has a relationship with the title of this paper. The source of the legal material used consists of; (1) The authoritative primary source of material means authority. The primary legal materials consist of legislation i.e. the primary legal material consists of legislation, the ruling judge, namely the laws and regulations relating to corruption including: a) Law No. 8 of 1981 about the code of criminal proceedings; b) Law No. 31 of 1999 on corruption eradication Juncto. Law No. 20 of 2001 concerning amendment to Law No. 31 of 1999 on corruption eradication; and c) Law No. 8 of 2010 on the prevention and eradication of money laundering crimes. (2) Source of secondary material which is all publications on the law include textbooks, legal journals, websites and other writings relating to the title of this paper.Legal research materials are processed and analyzed qualitatively, namely analyzing materials based on their quality and give a prescription to existing legal issues. Legal research is done by dissecting a book or law relating to a specified legal issue or in other words the research conducted is the literature research so that the research activities above can be obtained broader material for discussion or exposure in a systematic and understandable form of sentences, which are subsequently drawn conclusions and suggestions. 


\subsection{Research Finding}

Corruption crimes constitute a behavior or action of one or more that violates the prevailing norms by using and/or misuse of power or opportunity through the procurement process, determination of the collection of receipts or The provision of facilities or other services performed on the acceptance and/or expense of money or wealth, storage of money or wealth and in other permits and/or services for the purpose of obtaining personal gain or So that direct or indirect harm to the interests and/or finances of the country/society (Kristian, 2015).Corruption crimes consist of illegal acts, beneficial themselves and groups illegally, and adversely affect the finances of the country or the country's economy and relate to power. Acts against the law are deeds that do or do not do anything related to its position or authority. To benefit oneself or a certain group illegally by doing or not doing something based on the authority is based on an unauthorized gain. The stage of money laundering consists of three phases, namely Placement, Layering and Integration. All three phases can occur at the same time once the transaction. It is done to avoid suspicion from the authorities.The stage is governed by the Act No. 8 of year 2010 on the prevention and eradication of money laundering crimes, the placement is the simplest stage, a step to change the money generated from crime activities into the form of a less inflicting loss and eventually entered into the network of financial system (according to the explanation of money laundering elements on the broad financial sense, not the narrow) (Garnasih, 2017).Layering or called coating stage, is the second stage where the perpetrators make transactions more complex and layered and assembled that are protected by various forms of anonymity for the purpose of hiding the source of the money. At this stage usually involves wire transfer using a number of accounts that are transferred to various countries in an attempt to conceal the origin of funds. Integration is the third or final stage that at this stage the perpetrators re-enter the funds that are being delayering into a valid transaction, and (as it were) has nothing to do with the origins of evil. This Integration is a ruse to provide legitimacy for the money of the proceeds of the crime, which includes the resale of stocks, houses, vessels, and jewelry (gold and diamonds). Many ways to do the integration, but often used are methods that come from the year 1930s namely the loan-back method or the default loan method. The loan-back method includes a large amount of deposits that are usually stored in overseas banks, and then banks make loans from the money deposited. The money gained from these loans can be used freely since the money can be tracked as money coming from legitimate transactions. Corruption criminal relationship with money laundering in the perspective of criminal law or 
legislation governing the relationship of money laundering and criminal offenses may be observed in Article 2 of the Law No. 8 of 2010 on the prevention and eradication of money laundering criminal that these provisions govern the original crimes (predicate crimes) namely: (1)corruption (2)bribery (3)narcotics (4)psychotropic (5)labor smuggling (6)smuggling immigrants (7)in the field of banking, and other criminal acts mentioned in the provisions of Article 2. It is a link or general regulatory relationship between corruption crimes and money laundering crimes. Money laundering crimes are an advanced act with the intent to conceal the crime of the result of a corruption act so that it can be enjoyed directly or to enjoy the benefits of the original crime. The term amalgamation, there are also those who refer to it as a translation of samenloop or concursus. Arrangements regarding the merger of the criminal act are found in the Chapter VI of the Book I of the Criminal Code, the combination of two or more criminal acts accounted for by a person in the framework of the declaration. The criminal acts that have occurred are in accordance with the formulated in the legislation (Kanter,...) While the occurrence itself can be only one action, two/more actions or some actions continue. The merger governs two criminal acts different from the inclusion where the perpetrator is more than one. The merger further directs the discussion to a tangible deed to two/more different types of criminal acts. Merger is a provision on how to resolve a criminal offence (criminal system or pipetting) in the event that one person has committed more than one criminal to which all criminal acts have never been checked and disconnected by the court.Concrete provisions governing and determining of: (a) How to supply or inspect (completing) matters; and (b) the way or the criminal system of enforcement against one person who has committed more than one criminal offence which all have not been examined and decided by the court (Chazawi,...). The merging of the continuing action or the VoortgezetteHandeling is when the acts are each evil or transgression, but there is such a relationship, so it must be seen as a continuing act. Here are some criteria for merging actions to continue: 1) If the behavior of an accused is an implementation of a forbidden decision; 2) If the behavior of an accused has caused some similar criminal acts; 3) The implementation of a criminal offence with another criminal act is not separated by a relatively long period of time (Lamintang, 2014).

\section{Findings And Conclusions}

The rationale of the formation of a line or merger of criminal acts is meant to confront a person to a judge who turned out to be doing some criminal action and 
there is not yet a trial. It is to limit the criminal rationing that is too extreme, but can also be to burden criminal.The way to resolve the matter by law is to deliver some of the criminal acts in a single docket and to serve it in one case by one of the judges and not broken also some things by self-proclaimed by some assembly judges. The embodiment of the law will also be contained in Article 141 of the Code of Law of the Criminal Procedure (KUHAP) or the first Article 250 No. 14 HIR. (Chazawi,.....). It can then be understood that the merger or the contemplation of criminal works is passed first through the endowment. The endowment includes the investigation process, investigation and prosecution. But merging things according to the Criminal Procedure Code (KUHAP) and the Criminal Code(KUHP) only regulates the public prosecutor that can incorporate the matter. This means that merging or contemplation according to the criminal code can only be done in the prosecution when referring to the criminal code. So that at the stage of investigation, there is no set regarding the merger or criminal act, so that the authority to conduct an endowment about the combined or a criminal offence is only conducted by the public prosecutor with the criteria or certain conditions in accordance with Article 141 KUHAP which states the following: The public prosecutor may perform the merger and make in one indictment, if at the same time or almost simultaneously receive some files Matter in terms of: a)Some criminal acts are performed by the same person and the importance of the examination does not make an obstacle to the merger, b)Some criminal acts that are related to each other, c)Some criminal acts that is not relevant to each other, but one with the other is something to do, which in this case the merger is necessary for the examination purpose. What is meant by the word "the merger is necessary for the examination purposes" is not called, and the explanation of the article says quite clearly, which is explained is the word "cooperating": a).By more than one who works together and performed at the same time, b).By more than one at different times and places, but it is the implementation of the evil agreement made by them before, c).By one or more with the intention of obtaining a tool to be used to do other delicts or to avoid themselves from EAS because of other delicts (Hamzah, 2016).

There are 3 forms of combined or concurrent criminal acts: 1). Merger of single actions, 2). Merger of plural actions, 3). Ongoing merger of actions. Against corruption and criminal acts of money laundering, the merger can use the continuing theory of joining actions or the VoortgezetteHandeling set out in Article 64 KUHP, which is the following formula: 1). If between the some actions that each constitute a crime or offence, there is such a relationship, so that it must be viewed as a continuing act, then only one criminal provision is established; If different then the applied ones are the ones that contain the toughest criminal threat; 2). The same is only applied to one criminal provision, if the act is convicted of falsification or destruction of the currency, and likewise use the goods that are either deleted or 
damaged.Thus the merger of the continuing action or VoortgezetteHandeiling is when the acts are each crime or transgression, but there is such a relationship, so it should be seen as an act continues. The merger of continuing actions is two or more acts or acts of criminal as either a crime or offence, both acts and criminal acts must have a relationship, and the time or place of occurrence is different even though the difference is not too long. This means that as soon as an action is completed it does not take a long time for the second or subsequent action to occur due to a need or necessity of the first action (relationship) of the second act. The second or subsequent action, already ridden, is done when the first action is performed. In case of corruption crimes and money laundering crimes, it can be combined using the theory of merging actions continuing above. By using the rationale that corruption criminal acts can generate wealth or treasury.After the criminal acts tend to want to enjoy or hide the money. Enjoy in the sense that the perpetrators want to spend or want to benefit from the property or financial result of the corruption. So the deed can be said to be a criminal act of money laundering. The fulfillment of a money laundering criminal is when an asset hidden or enjoyed is derived from a criminal offence in this case of corruption. Thus criminal acts of corruption and money laundering crimes are certainly less likely to have a long time lapse to do so. So what is meant in the explanation of action continues above can be fulfilled.

The merger of corruption criminal investigation with money laundering criminal act is governed by Article 74 of Law No. 8 of 2010 on the prevention and eradication of money laundering crimes that the money laundering investigation was conducted by the original criminal investigation. This means that money laundering investigators are not a different investigator than the original criminal investigator, in this case the corruption investigator, if the investigation is the same investigator as the original criminal investigation., that is, the possibility of merging the matter in the stage of an investigation is very large (Kristiana, 2015). The original criminal investigation investigator can investigate money laundering crimes when finding evidence of the initial money laundering criminal in the case of an investigation of the original criminal act according to its authority. The instructions on merging cases on an investigation paper found in Article 74 along with their explanation, become clearer with the formulation of Article 75 which was approved in terms of investigation to find sufficient preliminary evidence of the Criminal Act of Money Laundering.

To facilitate understanding, the merger of the investigation in the stage between money laundering criminal offence and corruption criminal act is possible in the following configuration: $a$ ). First configuration, in the event that investigators are investigating acts Money laundering, then in the development of investigators can 
trace the criminal act of his origin, $b$ ). The second configuration, in the case of the occurrence of money laundering crimes is known after a criminal investigation of origin, means that investigators are working to make a corruption criminal investigation (predicate crime), but in the midst of investigation The investigator finds money laundering crimes, c).The third configuration, in the case of investigators are investigating corruption crimes or predicate crime, then in the middle of the investigation in addition to discovering money laundering criminal acts that were originally being investigated, if found a criminal act of washing The money in which the criminal acts were originally outside of the corruption criminal or the predicate crimes being simulated. Furthermore, in the event of investigation is to conduct a response between corruption and money laundering conducted a file, meaning that although in the case of a file there are 2 (two) warrant investigation between criminal acts of corruption money laundering and criminal acts, they are still made one.Prosecution is the act of Prosecution to delegate criminal matters of the state court of competent jurisdiction to be accompanied by an indictment. The indictment as the foundation of the judge may conduct the examination and only within the confines of the claim letter/indictment that the judge will decide the indictment is an important basis for criminal proceedings because it is based on the things contained in the letter the judge will examine the matter. The urgency of the allegation of the indictment is crucial to the foundation of the merger. The merger can be known through the indictment that was constructed by the public prosecutor. Thus, in drafting the indictment in the case of incorporation by the public prosecutor must be careful. Merger in the prosecution according to the KUHP, the public prosecutor can place the matter and make it in one indictment, with the First criteria: some criminal acts committed by the same person and the examination make a barrier to the merger; Secondly, some criminal acts are related to one another; Thirdly, some criminal acts that are not related to each other, but one with the other is something to do, which in this case the merger is necessary for examination purposes. If the explanation is examined it is apparent that the incorporation of a corruption crime or predicate crime and money laundering crimes meet the criteria in which criminal acts are deemed to have had the same. It's just because the merger of corruption crimes and money laundering crimes should also be concerned about new institutions, it should be adjusted to the institutional competency arrangement.In the case of criminal process corruption, coupled with the crime of money laundering, the consequences of merging things in the prosecution stage. This means that among the causes of money laundering crimes with criminal acts of corruption are cumulative.However, if the original criminal investigation has been completed and filed into a case file and handed over to the public prosecutor, it turns out later in its development found a crime of money laundering with its predicate crime or vice versa in terms of investigating the crime of money laundering has been completed 
and become a case file and then handed over by the public prosecutor, then both of them in the prosecution stage the public prosecutor can combine the two cases to be united and submitted to the court in a case transfer. This means that technically the transfer of cases to the court of the first case file is awaiting the investigation of the second file which is finished and submitted to the public prosecutor the two files are transferred in one file transferred to the court with cumulative charges.

\section{Recommendations}

First, the legal basis of the merging of prosecution of corruption and money laundering must be contained in an article in the law to minimize the interpretation of the Investigators when handling money laundering cases originating from criminal acts of corruption or vice versa, namely handling cases of corruption criminal acts that indicate the crime of money laundering. Secondly, it is necessary to merge the prosecution of criminal acts of corruption and money laundering with the coordination of investigators in order to recover the losses / economy of the country and minimize the overlapping authority of the investigators and the creation of criminal objectives.

\section{REFERENCES}

